\title{
Lupin seeds lower plasma lipid concentrations and normalize antioxidant parameters in rats
}

\author{
By M. Osman, G.I. Mahmoud, R.M. Romeilah and S.A. Fayed ${ }^{\star}$ \\ Biochemistry Department, Faculty of Agriculture, Cairo University, Giza, Egypt. \\ $\left({ }^{\star}\right.$ Corresponding author: sayedfayed@yahoo.com)
}

\section{RESUMEN}

Semillas de altramuces bajan la concentración de lípidos plasmáticos y normaliza los parámetros antioxidantes en ratas.

Este estudio fue diseñado para evaluar semillas de altramuces dulces y amargas como agentes que bajan los lípidos y estudiar su efecto en la actividad antioxidante en ratas hipercolesterolémicas. El nivel de lípidos en plasma, malondialdehido (MDA) y glutatión reducido (GSH), así como la actividad transaminasa (ALT y AST), lactato deshidrogenasa (LHD) en plama, superóxido dismutasa (SOD) y glutatión peroxidasa (GPx) en eritrocitos, glutatión reductasa (GR) en plasma, glutatión-S- trnasferasa (GST) y catalasa (CAT) fueron examinadas. La dieta inductora de hipercolesterolemia se manisfesto mediante la elevación de los lípidos totales (TL), del colesterol total (TC), de los triglicéridos, de la LDL-C y de los niveles de MDA, de las actividades ALT, AST, LDH y del descenso de GSH y enzimas antioxidantes. La suplementación de dietas inductoras de hipercolesterolemia con semillas de altramuces dulces y amargas bajo significativamente los niveles en plasma de TL, TC, TG y LDL-C. Las actividades ALT, AST y LDH decrecieron ligeramente en grupos tratados comparados con el grupo hipercolesterolémico (HC). Por otra parte, el contenido de GSH aumento significativamente mientras que el MDA decreció significativamente en los grupos tratados comparados con el grupo HC. Además, las semillas de altramuces amargas mejoraron las enzimas antioxidantes comparadas con el grupo HC. En general, los resultados indican que, el suplemento con semillas amargas es mejor que con semillas de altramuces dulces. Estos resultados sugieren que el efecto hipercolesterolémico del suplemento con semillas de altramuces dulces y amargas podrían ser debiadas a su capacidad para bajar los nivleles en plasma de colesterol, así como una ralentización del proceso de peroxidación lipídica y un aumento de la actividad enzimática antioxidante.

PALABRAS-CLAVE: Altramuz amargo - Altramuz dulce - Estres oxidativo - Hipercolesterolemia - Rata.

\section{SUMMARY}

Lupin seeds lower plasma lipid concentrations and normalize antioxidant parameters in rats.

This study was designed to test bitter and sweet lupin seeds for lipid-lowering and for their antioxidative activities in hypercholesterolemic rats. The levels of plasma lipid, malondialdehyde (MDA) and whole blood reduced glutathione (GSH), as well as the activities of transaminases (ALT and AST), lactate dehydrogenase (LDH) in plasma, superoxide dismutase (SOD), glutathione peroxidase (GPx) in erythrocytes and plasma glutathione reductase (GR), glutathione-S-transferase (GST) and catalase (CAT) were examined. A hypercholesterolemia-induced diet manifested in the elevation of total lipids (TL), total cholesterol (TC), triglycerides (TG), LDL-C and MDA levels, ALT, AST, LDH activities and the depletion of GSH and enzymic antioxidants. The supplementation of a hypercholesterolemia-induced diet with bitter and sweet lupin seeds significantly lowered the plasma levels of TL, TC, TG and LDL-C. ALT, AST and $\mathrm{LDH}$ activities slightly decreased in treated groups compared with the hypercholesterolemic group $(\mathrm{HC})$. Furthermore, the content of GSH significantly increased while MDA significantly decreased in treated groups compared with the HC group. In addition, the bitter lupin seed group improved enzymic antioxidants compared with the $\mathrm{HC}$ group. In general, the results indicated that the bitter lupin seed supplements are better than those containing sweet lupin seeds. These results suggested that the hypocholesterolemic effect of bitter and sweet lupin seed supplements might be due to their abilities to lower the plasma cholesterol level as well as to slow down the lipid peroxidation process and to enhance the antioxidant enzyme activity.

KEY-WORDS: Bitter lupin - Hypercholesterolemia Oxidative stress - Rats - Sweet lupin.

\section{INTRODUCTION}

Legume seeds are an abundant source of proteins and, among them, lupin is one of the richest. Indeed, lupin seed deserves greater interest as a result of its chemical composition and increased availability in many countries in recent years. Lupin is a nonstarch leguminous seed with high protein content, almost as high as that of soybean (about 35\% of the dry weight), relatively low oil content (Duranti et al., 2008) and a lack of antinutritional substances. The amount of antinutritional compounds found in other legumes, such as alkaloids, saponins, tannins and trypsin inhibitor, is minimal in lupin (Van Barneveld, 1999). Lupin cultivation is at least 2,000 years old and most likely began in Egypt or in the general Mediterranean region. The lupin plant, like other grain legumes (beans, peas, lentils, etc.) fixes atmospheric nitrogen, and produces seeds high in protein. There are over 300 species of the genus Lupinus (L.) (Putnam et al., 1989). Seeds of several species of lupins have been used as food for 3,000 years in the Mediterranean area (Gladstones, 1998). These bitter seeds had to be soaked in water 
before consumption, to remove most of their alkaloid content (Petterson, 1998). From the second half of the 20th century onward, low-alkaloid varieties of white lupin (Lupinus albus), yellow lupin (Lupinus luteus), and blue lupin (Lupinus angustifolius) have been domesticated and selected (Cowling et al., 1998). In 2004, sweet varieties of these three species were mainly cultivated in several parts of Australia, Europe, and South America (Martins et al., 2005) and used for animal feed and food applications (Sirtori et al., 2010).

Hypercholesterolemia and its implications in cardiovascular diseases is a major problem in human health, and much attention has been paid to dietary intervention as a tool for its prevention and treatment (Kerckhoffs et al., 2002). Legumes have shown hypocholesterolemic effects in human and animal models (Martins et al., 2004), but these studies have mainly been done with soybean or its components. Therefore, studies involving other legumes, such as lupins, may clarify the mechanism by which plasma cholesterol is reduced and lead to the identification of new functional foods and/or components (Martins et al., 2005). There is limited information on the physiological effects of lupin seeds, particularly on the lipid metabolism. Viveros et al. (2007) reported a lower concentration of plasma cholesterol and triglycerides when lupins (Lupinus albus) were included in chicken diets. In addition, several studies have shown that this legume is characterized by hypocholesterolaemic (Bettzieche et al., 2008; Sirtori et al., 2004 and Spielmann et al., 2007), anti-atherogenic (Marchesi et al., 2008), hypotensive (Lee et al., 2009 and Pilvi et al., 2006), and hypoglycaemic activities (Hall et al., 2005a and Lee et al., 2006).

The present study was designed to compare the effect of bitter and sweet lupin seeds in protecting experimental animals fed a hypercholesterolemiainduced diet of oxidative stress and hypercholesterolemia.

\section{MATERIALS AND METHODS}

\subsection{Materials}

The seeds of bitter and sweet lupin varieties (Lupinus albus) were purchased from the National Research Center (NRC), Ministry of Agriculture, Giza, Egypt. The seeds were milled well into fine powders.

\subsection{Animals and diets}

Twenty-four male Sprague-Dawley rats weighing $100 \pm 10 \mathrm{~g}$ were purchased from the animal house of Helwan Station for Experimental Animals, Helwan, Egypt. They were raised in the animal house of the Biochemistry Department, Faculty of Agriculture, Cairo University, Giza, Egypt. The animals were housed in polyethylene cages in groups of six rats per cage in a controlled environment $\left(25 \pm 2^{\circ} \mathrm{C}, 50\right.$ $60 \%$ relative humidity and 12 -hour light-dark cycle). The animals were fed ad libitum with a basal diet and water for two weeks and were then randomly assigned to 4 groups (6 rats each): normal control group (NC), receiving basal diet consisting of corn starch $65 \%$, casein $10 \%$, corn oil $10 \%$, salt mixture $4 \%$, vitamin mixture $1 \%$ and cellulose $10 \%$ (AOAC,2000), high-cholesterol control group (HC) receiving hypercholesterolemia-induced diet which was prepared in the same way as the basal diet, except that the $10 \%$ corn oil portion was replaced with $10 \%$ sheep perineal fat and it was supplemented with $1 \%$ cholesterol and $0.25 \%$ cholic acid (Fukushima et al., 1997). The bitter lupin group was fed hypercholesterolemia-induced diets supplemented with $5 \%$ bitter lupin seeds. The sweet lupin group received hypercholesterolemia-induced diets supplemented with $5 \%$ sweet lupin seeds.

\subsection{Experimental design}

During the experimental period (4 weeks), water and diets were available ad libitum. At the end of the experiment, all the animals were scarificed by decapitation. Blood samples were collected in three heparinized tubes. The first one $(0.1 \mathrm{ml}$ blood) was used for the determination of reduced glutathione $(\mathrm{GSH})$, the second heparinized tube $(0.5 \mathrm{ml}$ blood) was used to extract the erythrocytes lysate according to the procedure of Quist (1980) in order to study antioxidant enzymes. The third heparinized tube was centrifuged at $2500 \mathrm{rpm}$ at $37^{\circ} \mathrm{C}$ for 15 min to separate the plasma.

\subsection{Biochemical analysis}

Lipid analysis

The total lipids in plasma (TL), triglycerides (TG), total cholesterol (TC), low density lipoprotein cholesterol (LDL-C) and high density lipoprotein cholesterol (HDL-C) were determined according to Knight et al. (1972), Fossati and Prencipe (1982), Allain et al. (1974), Levy (1981) and Burstein (1970), respectively. The atherogenic Index (Al) was calculated according to Lee and Niemann (1996) using following equation:

$$
\text { Atherogenic Index }(\mathrm{Al})=\frac{\text { Total cholesterol }-\mathrm{HDL}-\mathrm{C}}{\mathrm{HDL}-\mathrm{C}}
$$

\section{Determination of $L D H, A S T$ and $A L T$ activities}

The lactate dehydrogenase (LDH) activity in plasma was determined according to the method of Young (2001). Aspartate aminotransferase (AST) and alanine aminotransferase (ALT) activities were measured colorimetricaly in plasma according to the method described by Reitman and Frankel (1957). 


\section{Determination of glucose}

The plasma glucose level was determined according to Trinder (1969).

\section{Determination of lipid peroxidation}

Plasma lipid peroxidation was estimated by measuring the thiobarbituric acid reactive substances (TBARS) and was expressed in terms of malondialdehyde (MDA) content, according to the method of Uchiyama and Mihara (1978). The MDA values were estimated using 1,1,3,3-tetraethoxy propane as the standard.

\section{Determination of non-enzymic antioxidants (GSH)}

Reduced glutathione (GSH) in whole blood was determined by the method of Beutler et al. (1963). This method was based on the reaction of GSH with 5,5 dithiobis(2-nitrobenzoic acid) to give a yellow compound that absorbs at $412 \mathrm{~nm}$.

\section{Determination of enzymic antioxidant activities}

Superoxide dismutase (SOD) and glutathione peroxidase (GPx) in erythrocytes were assayed by the methods of Nishikimi et al. (1972) and Paglia and Valentine (1970), respectively. Plasma glutathione reductase (GR) activity was assayed by the method of Goldberg and Spooner (1983). The enzyme activity was quantified by measuring the disappearance of $\mathrm{NADPH}$ at $340 \mathrm{~nm}$. Plasma glutathione-S-transferase (GST) activity was determined using the procedure of Habig et al. (1974) by measuring the conjugation of 1-chloro-2,4-dinitrobenzene (CDNB) with reduced glutathione. The conjugation is accompanied by an increase in absorbance at $340 \mathrm{~nm}$. The rate of increase is directly proportional to the GST activity. Plasma catalase (CAT) activity was determined according to the method of Aebi (1984).

\section{Statistical analysis}

A statistical analysis (standard deviation "SD" and standard error "SE") was carried out according to Fisher (1970). The LSD (Least significant difference) test was used to compare the significant differences between means of treatment (Waller and Duncan, 1969). The statistical package for social science S.P.S.S. (1999) program version was used for all analyses.

\section{RESULTS AND DISCUSSIONS}

In the present study, hypercholesterolemiainduced diet feeding for four weeks was chosen as the experimental model of early phase atherogenesis. Cholic acid addition enhances the hypercholesterolemic effect of cholesterol feeding (Shinnick et al., 1990). The role of bitter and sweet lupin seeds in countering the lipidemicoxidative aberrations accompanying diet-induced hypercholesterolemia have been investigated here.

Rats fed the hypercholesterolemia-induced diet (HC) developed hypercholesterolemia marked by a significant $(P<0.05)$ increase in plasma total lipids (TL), triglycerides (TG), total cholesterol (TC), low density lipoprotein cholesterol (LDL-C), high density lipoprotein cholesterol (HDL-C) and atherogenic Index (Al) compared with the normal control rats (NC). Supplementation with bitter and sweet lupin seeds showed significant $(P<0.05)$ falls in total lipids, triglycerides, total cholesterol, LDL-C and $\mathrm{Al}$ and $\mathrm{a}$ insignificant increase in HDL-C compared with the hypercholesterolemic group $(\mathrm{HC})$ as shown in Tables (1 and 2). The best reduction in the lipids profile was recorded for the bitter lupin seed supplement; the levels of total lipids, total cholesterol, triglycerides, LDL-C and Al were decreased by $48.29 \%, 41.05 \%, 27.49 \%, 46.61 \%$, and $54.22 \%$, respectively. A significant increase in the HDL-C level was observed for the bitter lupin seed supplement. However, no significant change in the HDL-C level was observed for the sweet lupin seed supplement. The results show that bitter lupin seed supplemented diets are more effective against hypercholesterolemia than sweet lupin seeds. These results are in agreement with the observations of Rahman et al. (1996), Chango et al. (1998), Sirtori et al. (2004), Spielmann et al. (2007) and Bettzieche et al. (2008) using lipid seeds in rats; Eder et al. (1996) and Rubio et al. (2003) in

Table 1

Plasma total lipids, total cholesterol and triglycerides $(\mathrm{mg} / \mathrm{dl})$ in experimental rats

\begin{tabular}{lccc}
\hline \multicolumn{1}{c}{ Groups } & Total lipids & Total cholesterol & Triglycerides \\
\hline NC & $285.02 \pm 7.32^{\mathrm{d}}$ & $91.30 \pm 2.33^{\mathrm{c}}$ & $93.66 \pm 4.05^{\mathrm{c}}$ \\
$\mathrm{HC}$ & $1163.12 \pm 48.30^{\mathrm{a}}$ & $487.70 \pm 33.82^{\mathrm{a}}$ & $281.80 \pm 16.45^{\mathrm{a}}$ \\
Bitter lupin & $601.49 \pm 34.82^{\mathrm{c}}$ & $287.50 \pm 33.17^{\mathrm{b}}$ & $204.33 \pm 24.97^{\mathrm{b}}$ \\
Sweet lupin & $875.00 \pm 36.23^{\mathrm{b}}$ & $321.59 \pm 26.34^{\mathrm{b}}$ & $268.59 \pm 29.69^{\mathrm{ab}}$ \\
LSD & 107.98 & 83.58 & 65.23 \\
\hline
\end{tabular}

Values are expressed as means $\pm S E(n=6)$. Values with different superscript letters within the same column are significantly different $(P<0.05)$. 
Table 2

Plasma HDL-cholesterol, LDL-cholesterol (mg/dl) and Al in experimental rats

\begin{tabular}{lccc}
\hline \multicolumn{1}{c}{ Groups } & HDL-cholesterol & LDL-cholesterol & Al \\
\hline NC & $38.33 \pm 1.28^{\mathrm{bc}}$ & $37.05 \pm 3.30^{\mathrm{c}}$ & 1.38 \\
$\mathrm{HC}$ & $45.49 \pm 2.62^{\mathrm{ab}}$ & $370.99 \pm 33.63^{\mathrm{a}}$ & 9.72 \\
Bitter lupin & $52.74 \pm 2.93^{\mathrm{a}}$ & $198.07 \pm 29.73^{\mathrm{b}}$ & 4.45 \\
Sweet lupin & $37.58 \pm 2.53^{\mathrm{c}}$ & $235.27 \pm 21.73^{\mathrm{b}}$ & 7.56 \\
LSD & 7.47 & 76.90 & \\
\hline
\end{tabular}

Values are expressed as means $\pm S E(n=6)$. Values with different superscript letters within the same column are significantly different $(P<0.05)$.

chickens; and Martins et al. (2005) in intact and ileorectal anastomozed pigs.

The lupin seed contains high amounts of protein and viscous nonstarch polysaccharides (NSP) that could modulate the intestinal absorption of sterols and thus cholesterolemia. Many dietary factors have been reported to contribute to the hypocholesterolemic effect of dietary legumes. Sirtori et al. (2004) showed that lupin protein isolates were able to reduce total plasma and very low density lipoprotein + LDL cholesterol concentrations in rats. This effect was associated with the stimulation of LDL receptors by a well-defined protein component in the lupin seeds, as demonstrated by in vitro studies. Yoshie-Stark and Wäsche (2004) also showed in in vitro studies that the application of lupin-isolated protein had the capacity to bind bile acids to nearly the same extent as cholestyramine. Similarly, Martins et al. $(2004,2005)$ found that feeding raw peas and whole blue lupin seeds to pigs exerted a marked hypocholesterolemic effect. This effect was mainly the consequence of a marked decrease in the intestinal absorption of cholesterol probably modulated by bile acid reabsorption and a higher content of dietary phytosterols. The presence of NSP fraction in the diets is another factor that could affect the cholesterol metabolism. Elevated levels of NSP, in particular the soluble fraction, lead to decreased nutrient digestion and absorption in poultry (Choct and Annison, 1990). The study by Viveros et al. (2007) showed an increase in intestinal viscosity and a reduction in cecal $\mathrm{pH}$, suggesting that the carbohydrates in the lupin seeds could be responsible for these effects. Increased intestinal content supernatant viscosity is highly correlated with reduced serum and liver cholesterol (Gallaher et al., 1993) and reductions in cholesterol absorption (Carr et al., 1996) in hamsters. Increased bile acid excretion represents another mechanism by which a reduction in cholesterol can be produced. Costa et al. (1994) demonstrated that viscous NSP can enhance bile secretion and subsequently result in a significant loss of these acids in the feces of rats. The continued drain of bile acids and lipids by sequestration and increased elimination as fecal acidic and neutral esterols may ultimately influence the absorption of lipids and cholesterol in the intestine. Although soluble dietary fiber was known to be an effective hypocholesterolemic agent, the insoluble dietary fiber of legume seeds has also been reported to be effective in lowering serum cholesterol in hypercholesterolemic men (Hughes, 1991). The addition of lupin kernel fiber to the diet provided favorable changes to some serum lipid (total cholesterol, high-density lipoprotein cholesterol) (Hall et al., 2005b). These studies confirm the results of the present study. In fact, bitter lupin seeds may prevent an increase in the factors causing coronary heart diseases (CHD) and cardiovascular diseases (CVD) more than sweet lupin seeds, so they may also prevent atherosclerosis.

Table (3) presents the results of plasma AST, ALT and LDH activities in the experimental rats. There were significant increases $(P<0.05)$ in the plasma AST, ALT and LDH activities of hypercholesterolemic rats $(\mathrm{HC})$ as compared to normal control rats (NC). The present findings are in agreement with those obtained by Ahmed et al. (1987) who found that hypercholesterolemia states significantly stimulate ALT and AST activity in the

Table 3

Plasma ALT, AST and LDH activities (U/L) in experimental rats

\begin{tabular}{lccc}
\hline \multicolumn{1}{c}{ Groups } & ALT & AST & LDH \\
\hline NC & $22.35 \pm 0.07^{\mathrm{d}}$ & $25.22 \pm 0.46^{\mathrm{c}}$ & $560.5 \pm 15.4^{\mathrm{c}}$ \\
$\mathrm{HC}$ & $36.37 \pm 0.53^{\mathrm{a}}$ & $98.99 \pm 6.63^{\mathrm{a}}$ & $1232.89 \pm 20.5^{\mathrm{a}}$ \\
Bitter lupin & $28.14 \pm 0.38^{\mathrm{c}}$ & $61.17 \pm 4.51^{\mathrm{b}}$ & $963.7 \pm 21.7^{\mathrm{b}}$ \\
Sweet lupin & $31.16 \pm 0.40^{\mathrm{b}}$ & $70.35 \pm 5.16^{\mathrm{b}}$ & $1127.0 \pm 74.5^{\mathrm{a}}$ \\
LSD & 1.19 & 14.71 & 151.05 \\
\hline
\end{tabular}

Values are expressed as means $\pm S E(n=6)$. Values with different superscript letters within the same column are significantly different $(P<0.05)$. 
plasma. Plasma ALT activity significantly decreased $(P<0.05)$ in rats fed the hypercholesterolemiainduced diets supplemented with bitter or sweet lupin seeds by $22.63 \%$ and $14.32 \%$, respectively compared with the hypercholesterolemic control (HC). Moreover, plasma AST activity significantly decreased in all treated groups as compared to the hypercholesterolemic control (HC). The highest decrease in plasma AST activity was recorded for the bitter lupin seed supplement (38.20\%). No changes in LDH activity was observed for the sweet lupin seed group when compared with the hypercholesterolemic control group (HC). However, there was a significant decrease in the plasma LDH activity of the bitter lupin seed group as compare to the hypercholesterolemic group $(\mathrm{HC})$.

Mansour et al. (2002) found that a treatment of alloxan-diabetic rats with Lupinus albus for 28 consecutive days could restore the activities of AST, ALT and LDH to their normal levels. A possible explanation for the effect of lupin seeds on the activities of AST, ALT and LDH in plasma and liver is that these seeds may inhibit the liver damage induced by hypercholesterolemia.

The liver is a central organ for many physiological and biochemical processes necessary for the maintenance of life (Souba and Wilmore, 1983). Morphological alterations that occur in the liver affect many metabolic processes in the organism. Peroxide formation induced by hypercholesterolemia (Sudhahar et al., 2007) results in the release of some enzymes by interacting with cellular structure and function. Thus, the serum activities of cellular enzymes such as transaminases, alkaline phosphatase, and lactate dehydrogenase do increase. With the increase in cellular membrane permeability, intracellular fluid transfers into intercellular space, resulting in muscle and liver cell degeneration.

In the present study, it was observed that as a result of hypercholesterolemia, enzymes such as AST, ALT and LDH were released into the blood. Their increase in the plasma activities of these enzymes was directly proportional to the degree of cellular damage. These values decreased with bitter and sweet lupin seed supplements.

Rats fed hypercholesterolemia-induced diets showed a significant $(P<0.05)$ increase and a decrease in plasma malondialdehyde (MDA) level and blood reduced glutathione (GSH) content respectively compared to the normal control rats (Table 4). MDA significantly increased $(P<0.05)$ by $203.63 \%$ and $G S H$ significantly depleted $(P<0.05)$ by $31.13 \%$ in hypercholesterolemic rats $(\mathrm{HC})$. These results are related to the results of Kempaiah and Srinivasan (2004 and 2005). Supplementation of hypercholesterolemia-induced diets with bitter lupin seeds showed a significant $(P<0.05)$ decrease and an increase in MDA level and GSH content respectively compared with hypercholesterolemic rats (Table 4). The best results of MDA and GSH were recorded for the bitter lupin seed supplement. MDA significantly decreased $(\mathrm{P}<0.05)$ by $40.16 \%$ and $\mathrm{GSH}$ significantly increased $(\mathrm{P}<0.05)$ by $44.50 \%$ in the bitter lupin seed group compared with hypercholesterolemic rats (HC). However, no significant changes in MDA and GSH levels were observed for the sweet lupin seed supplement.

MDA level is the most important factor for indicating an increased peroxidative level, while glutathione is a substance with an important role in cell detoxification and protection from hazardous compounds. Glutathione is synthesized in the erythrocytes and is found in living cells. It has been reported that cellular glutathione has an important function against chemical agents by protecting the cell membrane integrity. A decrease in the amount of glutathione and an increase in the amount of MDA may result in the destruction of membrane integrity (Kempaiah and Srinivasan, 2005 and Tauseef et al., 2007). In this study, the decrease in the reduced glutathione and the increase in malondialdehyde levels of hypercholesterolemic group indicate that hypercholesterolemia damaged the integrity of the erythrocyte membrane. On the contrary, the observed increase in the amount of GSH and the decrease in MDA in the bitter lupin seed group indicate that bitter lupin seeds effectively protect membrane integrity.

Bitter lupin seeds have a hypolipidemic effect which may prevent the increase in lipid peroxidatin, therefore depleting GSH in hypercholesterolemia.

The study reported by Sheweita et al. (2002) showed that the level of the free radicals, TBARS, was decreased in the Termis-treated diabetic rats for 28 consecutive days. The maintenance of free radical levels in Termis-treated diabetic animals

Table 4

Whole blood GSH (mg/dl) and plasma MDA (nmol/L) and glucose (mg/dl) in experimental rats

\begin{tabular}{lccc}
\hline \multicolumn{1}{c}{ Groups } & GSH & MDA & Glucose \\
\hline NC & $45.68 \pm 3.44^{\mathrm{a}}$ & $29.98 \pm 1.11^{\mathrm{c}}$ & $86.10 \pm 2.93^{\mathrm{c}}$ \\
HC & $31.46 \pm 1.07^{\mathrm{b}}$ & $91.03 \pm 2.60^{\mathrm{a}}$ & $114.09 \pm 2.77^{\mathrm{a}}$ \\
Bitter lupin seeds & $45.46 \pm 3.29^{\mathrm{a}}$ & $54.47 \pm 4.69^{\mathrm{b}}$ & $94.47 \pm 3.21^{\mathrm{bc}}$ \\
Sweet lupin seeds & $33.60 \pm 3.60^{\mathrm{b}}$ & $93.46 \pm 4.54^{\mathrm{a}}$ & $105.10 \pm 5.69^{\mathrm{ab}}$ \\
LSD & 9.83 & 10.96 & 12.56 \\
\hline
\end{tabular}

Values are expressed as means \pm SE $(n=6)$. Values with different superscript letters within the same column are significantly different $(P<0.05)$. 
might be due to the presence of phenolic compounds which are known to be good scavengers for free radicals (Novikov and Kagan, 1985).

The plasma glucose level of hypercholesterolemic rats $(\mathrm{HC})$ was significantly $(\mathrm{P}<0.05)$ increased compared to the normal control (NC). However, a significant improvement in the plasma glucose level was observed for the bitter lupin seed treated group compared with the hypercholesterolemic group (HC). However, no significant change was observed for the sweet lupin seed group.

Lupinus albus (Termis) exerted hypoglycemic effects and an increase in the level of serum insulin in normal and diabetic subjects as well as in normal and alloxan-diabetic animals (Youness et al., 1985; Eskander and Won Jun, 1995 and Mansour et al., 2002).

The reduction of serum glucose level in the current experiment, by a lupin supplemented diet, is in agreement with the in vitro and in vivo study between a lupin seed protein (namely, conglutin $\gamma$ ) and insulin, reported recently by Magni et al. (2004). The effect of the oral administration of conglutin $\gamma$ on the glycemic levels of rats subjected to glucose overloading resulted in a significant reduction in rat glycemia.

Table (5) displays the activities of antioxidant enzymes in erythrocytes and plasma. The erythrocytes superoxide dismutase (SOD), plasma glutathione reductase (GR) and glutathione-Stransferase $(G S T)$ were significantly $(P<0.05)$ inhibited $(24.51 \%, 24.49 \%$ and $24.25 \%$, respectively) in hypercholesterolemic rats ( $\mathrm{HC})$. A slight inhibition in the activities of erythrocytes glutathione peroxidase (GPx) and plasma catalase (CAT) was observed in the hypercholesterolemic group ( $\mathrm{HC})$ compared to the normal control group (NC). Hypercholesterolemiainduced diets supplemented with bitter lupin seeds improved the activities of these enzymes. However, no significant changes were observed for sweet lupin seed supplements. The effect of bitter lupin seeds in this context was even better since the levels of enzymes were brought almost too nearly that of the normal control (NC). Bitter lupin seed supplements stimulated SOD, GR and GST activities by $20.68 \%$, $23.36 \%$ and $18.84 \%$, respectively. There was an increase in the levels of these antioxidant enzymes and GSH in the treated groups, thereby indicating that treatment with bitter lupin seed supplements protects against the oxidative stress induced by the depletion of enzymic and non-enzymic antioxidants.

A hypercholesterolemia-induced diet brings about a remarkable modification in the antioxidant defence mechanisms. Studies have shown that hypercholesterolemia diminishes the antioxidant defence system and decreases the activities of SOD, CAT, GPx and GST, elevating the lipid peroxide content (Fki et al., 2005 and Kempaiah and Srinivasan, 2005).

Oxidative stress occurred as a consequence of the imbalance between the production of reactive oxygen species and the antioxidative process in favor of radical production (Dringen, 2000). In the current study, the decrease in the antioxidant enzymes produced a failure of the antioxidant defence system to overcome the influx of reactive oxygen species generated by the hypercholesterolemic diet. However, the inhibition of enzymes involved in free radical removal led to the accumulation of $\mathrm{H}_{2} \mathrm{O} 2$, which promoted lipid peroxidation and modulation of DNA, altered gene expression and cell death (Halliwell and Gutteridge, 1999). Glutathione (GSH) was the major compound in the intracellular redox status regulation and it was an important substrate and cofactor in the metabolism of many drugs. The decrease in the activities of GPx and GST could result directly from the decreased levels of GSH following the hypercholesterolemia-induced diet since both enzymes were independent on GSH for their activity. The positive correlation observed in our study between GSH, Gpx, GR and GST support these findings.

In this study, the hypolipidemic and hypocholesterolemic effects of bitter lupin seed supplements improved antioxidant enzyme activities with an increasing antioxidant GSH level and a decreasing lipid peroxide level (MDA)

It could be summarized that both bitter and sweet lupin seed supplements protected and prevented the increase in hypercholesterolemic agents compared with the hypercholesterolemic group $(\mathrm{HC})$; but the effects of the bitter lupin seed supplement was better than the sweet lupin seed supplement. In addition, the bitter lupin seed supplement significantly decreased plasma transaminases and LDH activities. A slight decrease in transaminases activities was observed with the lupin seed supplement, while no change in LDH activity was observed. It can also be said that

Table 5

Erythrocytes SOD (U/ml) and GPx (U/L) and plasma CAT, GR and GST (U/L) activities in experimental rats

\begin{tabular}{lccccc}
\hline \multicolumn{1}{c}{ Groups } & SOD & GPx & CAT & GR & GST \\
\hline NC & $180.76 \pm 7.17^{\mathrm{a}}$ & $346.36 \pm 31.36^{\mathrm{a}}$ & $422.73 \pm 30.83^{\mathrm{a}}$ & $36.67 \pm 3.93^{\mathrm{a}}$ & $41.82 \pm 2.08^{\mathrm{a}}$ \\
HC & $136.46 \pm 3.13^{\mathrm{c}}$ & $310.27 \pm 17.89^{\mathrm{a}}$ & $377.74 \pm 31.36^{\mathrm{a}}$ & $27.69 \pm 1.73^{\mathrm{bc}}$ & $31.68 \pm 2.73^{\mathrm{b}}$ \\
Bitter lupin & $164.68 \pm 8.54^{\mathrm{ab}}$ & $341.26 \pm 32.43^{\mathrm{a}}$ & $384.18 \pm 27.23^{\mathrm{a}}$ & $34.16 \pm 0.96^{\mathrm{ab}}$ & $37.65 \pm 2.18^{\mathrm{ab}}$ \\
Sweet lupin & $148.43 \pm 5.02^{\mathrm{bc}}$ & $313.93 \pm 14.09^{\mathrm{a}}$ & $353.11 \pm 20.11^{\mathrm{a}}$ & $24.62 \pm 1.97^{\mathrm{c}}$ & $31.48 \pm 1.69^{\mathrm{b}}$ \\
LSD & 24.71 & 67.32 & 90.37 & 6.91 & 8.61 \\
\hline
\end{tabular}

Values are expressed as means $\pm S E(n=6)$. Values with different superscript letters within the same column are significantly different $(P<0.05)$. 
the bitter lupin seed supplement kept MDA lower than that in the hypercholesterolemic diet. Moreover, the bitter lupin seed supplement kept GSH higher than that in the hypercholesterolemic diet. On the other hand, bitter lupin seed supplements improve antioxidant enzymes better than sweet lupin seeds as compared to the hypercholesterolemic control. In general, the lipids profile, transaminases, LDH, MDA of bitter and sweet lupin groups were still higher than in the normal control group, while GSH and enzymic antioxidants were increased for the bitter lupin seed group, they were still lower than those in the normal control group.

Bitter and sweet lupin seeds are natural, normal, healthy and appropriate for reducing oxidative stress, hyperlipidemic, hypertriglyceridemic and hypercholesterolemic factors. These findings stand in stark contrast to the use of hypercholesterolemic drugs that have life-threatening side effects like aching or weakness of skeletal muscles.

Finally the present results clearly illustrate the possibility of using bitter lupin seeds as hypocholesterolemic and antioxidative agents, although further studies using higher concentrations of the seeds may be needed to normalize the rest of the biochemical parameters. It is our opinion, however, that serious experiments must be carried out on human patients.

\section{REFERENCES}

Aebi H. 1984. Catalase in vitro. Method. Enzymol. 105, 121-126.

Ahmed FA., El-Desoky GE, El-Saadawy SS and Ramadan ME. 1987. Carbohydrates and lipids changes in rats administrated certain synthetic and natural food colors. Minia J. Agric. Res. Dev. 9, 11011116.

Allain CC, Poon LS, Chan CS, Richmoud W and Fu PC. 1974. Enzymatic determination of total serum cholesterol. Clin. Chem. 20, 470-475.

AOAC 2000. Method of analysis. Association of Official Agriculture Chemists. Washington D.C.USA, $17^{\text {th }}$ ed.

Bettzieche A, Brandsch C, Weibe K, Hirche F, Eder K and Stangl Gl. 2008. Lupin protein influences the expression of hepatic genes involved in fatty acid synthesis and triacylglycerol hydrolysis of adult rats. Br. J. Nutr. 99, 952-962.

Beutler E, Duron O and Kelly BM, 1963. Improved method for the determination of blood glutathione. $J$. Lab. Clin. Med. 61, 882-888.

Burstein M. 1970. A fully enzymatic colorimetric determination of HDL cholesterol in the serum. Lipid Res. 1, 583-595.

Carr TP, Gallaher DD, Yang CH and Hassel CA. 1996. Increased intestinal contents viscosity and cholesterol absorption efficiency in hamsters fed hydroxypropyl methylcellulose. J. Nutr. 126, 1463-1469.

Chango A, Villaume C, Bau HM, Schwertz A, Nicolas J P and Mejean L. 1998. Effects of casein, sweet white lupin and sweet yellow lupin diet on cholesterol metabolism. J. Sci. Food Agric. 76, 303-309.

Choct M and Annison G. 1990. Antinutritive activity of wheat pentosans in broiler diets. Br. Poult. Sci. 31, 811-821.
Costa NMB, Low AG, Walker AF, Owen RW and Englyst NH. 1994. Effect of baked beans (Phaseolus vulgaris) on steroid metabolism and non-starch polysaccharides output of hypercholesterolaemic pigs with or without an ileorectal anastomosis. Br. J. Nutr. 71, 871-886.

Cowling WA, Huyghe C and Swiecicki W. 1998. Lupin breeding. In Lupins as Crop Plants: Biology, Production, and Utilization. J.S. Gladstones, C.A. Atkins, and J. Hamblin, editors. CAB International, Wallingford, UK. 93-120.

Dringen R. 2000. Metabolism and functions glutathione in brain. Prog. Neurobiol. 62, 649-671.

Duranti M, Consonni A, Magni C, Sessa F and Scarafoni A. 2008. The major proteins of lupin seed: Characterisation and molecular properties for use as functional and nutraceutical ingredients. Trends Food Sci. Technol. 19, 624-633.

Eder K, Roth-Maier D and Kirchgessner M. 1996. The effect of enzyme supplements and high amounts of white lupins on concentrations of lipids in serum and meat in fattening chickens. Arch. Anim. Nutr. 49, 221-228.

Eskander EF and Won Jun H. 1995. Hypoglycaemic and hyperinsulinemic effects of some Egyptian herbs used for the treatment of diabetes mellitus (type II) in rats. Egypt. J. Pharm. 36, 331-342.

Fisher RA. 1970. Statistical method for research workers Edinburgh ed. 14, Oliver and Boyed, p. 140.

Fki I, Bouaziz M, Sahnoun Z and Sayadi S. 2005. Hypercholesterolemic effects of phenolic-rich extracts of Chemlali olive cultivar in rats fed a cholesterol-rich diet. Bioorg. Med. Chem. 13, 5362-5370.

Fossati P and Prencipe L. 1982. The determination of triglyceride using enzymatic methods. Clin. Chem. 28, 2077-2080.

Fukushima M, Takayama Y, Habaguchi T and Nakano M. 1997. Comparative hypocholesterolemic effects of capybara (Hydrochoerus hydrochaeris dabbenel) oil, horse oil and sardine oil in cholesterol-fed rats. Lipids 32, 391-395.

Gallaher DD, Hassel CA, Lee KJ and Gallaher C. 1993. Viscosity and fermentability as attributes of dietary fiber responsible for the hypocholesterolemic effect. J. Nutr. 123, 244-252.

Gladstones JS. 1998. Distribution, origin, taxonomy, history and importance. In Lupins as Crop Plants: Biology, Production, and Utilization. J.S. Gladstones, C.A. Atkins, and J. Hamblin, editors. CAB International, Wallingford, UK. 1-39.

Goldberg DM and Spooner RJ. 1983. Glutathione reductase. In: Bergmeyer HU, Bergmeyer J and Bral M. (ed). Methods of enzymatic analysis, $3^{\text {rd }}$ ed., vol. 3. Verlag Chemie, Weinheim, pp 258-265.

Habig W, Pabst M and Jakoby WB. 1974. Glulathione-Stransferase: The first enzymatic step in mercapturic acid formation. J. Biol. Chem. 249, 7130-7139.

Hall RS, Johnson SK, Baxter AL and Ball MJ 2005b. Lupin kernel fiber-enriched food beneficially modify some lipids in men. Eur. J. Clin. Nutr. 59, 325-333.

Hall RS, Thomas SJ and Johnson SK. 2005a. Australian sweet lupin flour addition reduces the glycaemic index of a white bread breakfast without affecting palatability in healthy human volunteers. Asia Pac. J. Clin. Nutr. 14, 91-97.

Halliwell B and Gutteridge JMC. 1999. The chemistry of the free radicals and related reactive species. In: Halliwell, B. and Gutteridge, J.M.C., editors. Free 
radicals in biology and medicine. $3^{\text {rd }}$ ed. Oxford: Oxford science publications, pp. 36-104.

Hughes JS. 1991. Potential contribution of dry bean dietary fiber to health. Food Technol. 9,122-126.

Kempaiah RK and Srinivasan K. 2004. Antioxidant status of red blood cells and liver in hypercholesterolemic rats fed hypolipidemic spices. Int. J. Vitam. Nutr. Res. 74, 199- 208.

Kempaiah RK and Srinivasan K. 2005. Influence of dietary spices on the fluidity of erythrocytes in hypercholesterolemic rats. Br. J. Nutr. 93, 81-91.

Kerckhoffs DAJM, Brouns F, Hornstra G and Mensink RP. 2002. Effects on the human serum lipoprotein profile of $\beta$-glucan, soy protein and isoflavones, plant sterols and stanols, garlic and tocotrienols. J. Nutr. 132, 2494-2505.

Knight JA, Anderson SJ and Rawle JM. 1972. Chemical bases of the sulfo-phosphovanillin reaction for estimating serum total lipids. Clin. Chem. 18, 199-202.

Lee Y, Mori T, Puddey I, Sipsas S, Ackland T and Beilin L. 2009. Effects of lupin kernel flour-enriched bread on blood pressure: A controlled intervention study. Am. J. Clin. Nutr. 89, 766-772.

Lee Y, Mori T, Sipsas S, Barden A, Puddey I and Burke V. 2006. Lupin-enriched bread increases satiety and reduces energy intake acutely. Am. J. Clin. Nutr. 84, 975-980.

Lee R and Niemann D. 1996. Nutritional Assessment $2^{\text {nd }}$ ed Mosby Missou USA.

Levy, A.L. 1981. A fully enzymatic colourimetric determination of LDL- cholesterol in the serum.Clin. Chem. 27, 653-662.

Magni C, Sessa F, Accardo E, Morazzoni P, Scarafoni A and Duranti M. 2004. Conglutin , a lupin seed protein, binds insulin in vitro and reduces plasma glucose levels in hyperglycaemic rats. J. Nutr. Biochem. 15, 646-650.

Mansour HA, Newairy AA, Yousef MI and Sheweita SA. 2002. Biochemical study on the effects of some Egyptian herbs in alloxan-induced diabetic rats. Toxicol. 170, 221-228.

Marchesi M, Parolini C, Diani E, Rigamonti E, Cornelli $\mathrm{L}$ and Arnoldi A. 2008. Hypolipidaemic and antiatherosclerotic effects of lupin proteins in a rabbit model. Br. J. Nutr. 4, 1-4.

Martins JM, Riottot M, de Abreu MC, Viegas-Crespo AM, Lança MJ, Almeida JA, Freire JB and Bento O. 2004. Dietary raw peas (Pisum sativum L.) reduce plasma total and LDL cholesterol and hepatic esterified cholesterol in intact and ileorectal anastomosed pigs fed cholesterol-rich diets. J. Nutr. 134, 3305-3312.

Martins JM, Riottot M, de Abreu MC, Viegas-Crespo AM, Lança MJ, Almeida JA, Freire JB and Bento O. 2005. Cholesterol-lowering effects of dietary blue lupin (Lupinus angustifolius L.) in intact and ileorectal anastomosed pigs. J. Lipid Res. 45, 1539-1547.

Nishikim, M, Roa NA and Yagi K. 1972. The occurrence of superoxide anion in the reaction of reduced phenazine methosulfate and molecular oxygen. Biochem. Biophys. Res. Commun. 46, 849-854.

Novikov KN and Kagan V. 1985. Stabilization of cytochrome $\mathrm{P} 450$ in hepatocytes by free radical scavenger of different nature. Acta Physiol. Pharmacol. Bulg. 11, 61-69.

Paglia DE and Valentine VW. 1970. Studies on the qualitative and quantitative characterization of erthyrocyte glutathione peroxidase. J. Lab. Clin. Med. 70, 158-178.
Petterson, D.S. 1998. Composition and food uses of lupins. In Lupins as Crop Plants: Biology, Production, and Utilization. J.S. Gladstones, C.A. Atkins, and J. Hamblin, editors. CAB International, Wallingford, UK. 353-384.

Pilvi TK, Jauhiainen T, Cheng ZJ, Mervaala EM, Vapaatalo $\mathrm{H}$ and Korpela R. 2006. Lupin protein attenuates the development of hypertension and normalises the vascular function of $\mathrm{NaCl}$-loaded Goto-Kakizaki rats. J. Physiol. Pharmacol. 57, 167176.

Putnam DH, Oplinger ES, Hardman LL and Doll JD. 1989. Lupin. In: Alternative field crops manual. Center for Alternative Plant and Animal Products, University of Minnesota, St. Paul.

Quist EE. 1980. Regulation of erythrocyte membrane shape by $\mathrm{Ca}^{2+}$. Biochem. Biophys. Res. Commun. 92, 631-637.

Rahman $\mathrm{MH}$, Hossain A, Siddiqua $\mathrm{A}$ and Hossain I. 1996. Hemato-biochemical parameters in rats fed Lupinus angustifolius (sweet lupin) seed protein and fiber fractions. J. Clin. Biochem. Nutr. 20, 99-111.

Reitman S and Frankel S. 1957. A colourimetric method for the determination of serum glutamic oxaloacetic and glutamic pyruvic transaminases. Am. J. Clin. Path. 28, 56-62.

Rubio LA, Brenes A and Centeno C. 2003. Effects of feeding growing broiler chickens with practical diets containing sweet lupin (Lupinus angustifolius) seed meal. Br. Poult. Sci. 44, 391-397.

S.P.S.S. 1999. Statistical Package for the Social Science, Inc. Chicago.

Sheweita SA, Newairy AA, Mansour HA and Yousef MI. 2002. Effect of some hypoglycemic herbs on the activity of phase I and II drug-metabolizing enzymes in alloxan-induced diabetic rats. Toxicol. 174, 131-139.

Shinnick FL, Lnk SL and Marlett JA. 1990. Dose response to a dietary oat bran fraction in cholesterol-fed rats. J. Nutr. 120, 561-568.

Sirtori CR, Lovati MR, Manzoni C, Castiglioni S, Duranti M, Magni C, Morandi S, D'Agostina A and Arnoldi A. 2004. Proteins of white lupin seed, a naturally isoflavone-poor legume, reduce cholesterolemia in rats and increase LDL receptor activity in HepG2 cells. J. Nutr. 134, 18-23.

Sirtori E, Resta D, Brambilla F, Zacherl C and Arnoldi A. 2010. The effects of various processing conditions on a protein isolate from Lupinus angustifolius. Food Chem. 120, 496-504.

Souba WW and Wilmore DW 1983. Postoperative alteration of arteriovenous exchange of amino acids across the gastrointestinal tract. Surgery 94, 342-350.

Spielmann J, Shukla A, Brandsch C, Hirche F, Stangl GI and Eder K. 2007. Dietary lupin protein lowers triglyceride concentrations in liver and plasma in rats by reducing hepatic gene expression of sterol regulatory element-binding protein-1c. Ann. Nutr. Metab. 51, 387-392.

Sudhahar V, Kumar SA, Sudharsan PT and Varalakshmi P. 2007. Protective effect of lupeol and its ester on cardiac abnormalities in experimental hypercholesterolemia. Vascul. Pharmacol. 46, 412-418.

Tauseef M, Sharma KK and Fahim M. 2007. Aspirin restores normal baroreflex function in hypercholesterolemic rats by its antioxidative action. Eur. J. Pharmacol. 556, 136143.

Trinder, P. 1969. Determination of blood glucose using an oxidation peroxidase system with a non carsinogenic chromogene. Ann. Clin. Biochem. 6, 24. 
Uchiyama M and Mihara M. 1978. Determination of malonaldehyde precursor in tissues by thiobarbituric acid test. Anal. Biochem. 86, 271-278.

Van Barneveld R J. 1999. Understanding the nutritional chemistry of lupin (Lupinus spp.) seed to improve livestock production efficiency. Nutr. Res. Rev. 12 , 203-230.

Viveros A, Centeno C, Arija I and Brenes A. 2007. Cholesterol-Lowering Effects of Dietary Lupin (Lupinus albus var Multolupa) in Chicken Diets. Poult. Sci. 86, 2631-2638.

Waller RA and Duncan DB. 1969. Aboys rule for symmetric multiple comparison problem. An. State Assoc. J. 65, 1485-1503.
Yoshie-Stark $Y$ and Wäsche A. 2004. In vitro binding of bile acids by lupin protein isolates and their hydrolysates. Food Chem. 88, 179-184.

Youness RI, Ahmaed HH, Fayez H, Mansour SA and Soliman FA. 1985. The hypoglycemic effects of some commonly used plants and seeds. Zool. Soc. Egypt. Bull. 35, 121-128.

Young DS. 2001. Effects of Disease on Clinical Laboratory Tests. $4^{\text {th }}$ ed. Washington, DC: American Association for Clinical Chemistry.

Recibido: $31 / 5 / 10$ Aceptado: 2/9/10 